\title{
EVALUASI MEMBANGKITKAN FUNGSI KEANGGOTAAN \\ PADA FUZZY MODEL MAMDANI
}

\author{
Rafiqa Dewi \\ Dosen STIKOM Tunas Bangsa Pematangsiantar, Sumatera Utara-Indonesia \\ Jalan Sudirman Blok A No. 1, 2, 3 Pematangsiantar \\ E-mail: rafiqa.atb@gmail.com
}

\begin{abstract}
Abstrak
Paper ini membahas tentang perbandingan dua bentuk dalam membangkitkan fungsi keanggotaan. Menentukan fungsi keanggotaan melalui segitiga sama kaki akan mendapatkan nilai menurun pada segitiga tersebut. Sedangkan pada segitiga siku-siku, setelah puncak segitiga tidak ada kemungkinan nilai menurun. Sehingga nilai yang diperoleh merupakan nilai menaik dan putus setelah puncak segitiga. Dihitung dengan model Mamdani, nilai output yang dihitung dengan segitiga sama kaki memiliki nilai yang lebih rendah dibandingkan dengan yang dihasilkan oleh segitiga siku-siku. Hal ini disebabkan segitiga siku-siku tidak memiliki bagian sisi yang menurun setelah puncak segitiganya, sehingga tidak memiliki pendekatan kepada variabel setelahnya.
\end{abstract}

Kata kunci : Algoritma fuzzy; fuzzy Mamdani; segitiga; fungsi keanggotaan 


\section{Pendahuluan}

Perbedaan cara dalam membangun fungsi keanggotaan dalam fuzzy telah banyak dibahas sebelumnya. Fungsi keanggotaan secara umum yaitu: segitiga, trapezoidal, Gaussian, Bell, Sigmoidal dan Polynomial. Dan segitiga merupakan fungsi yang paling dasar sebagai bentuk yang digunakan dalam melakukan pendekatan antar variabel menurut Zhao. J dan Bose. BK, 2002. Dalam hal ini penulis tertarik untuk membahas segitiga, dimana terdapat jenis-jenis segitiga yang kita ketahui diantaranya segitiga sama kaki dengan segitiga siku-siku, yang memiliki perbedaan mencolok pada bagian sisi kanan setelah puncak segitiga.

Tujuan penelitian adalah untuk menambah jenis pembangkitan membership function (MF), khususnya pada jenis segitiga dan menguji penerapan algoritma fuzzy model Mamdani pada MF segitiga siku-siku.

\section{Metode Penelitian}

Berbagai bentuk untuk membangunkan fungsi keanggotaan dapat digambarkan sebagaimana terlihat pada gambar 1 .
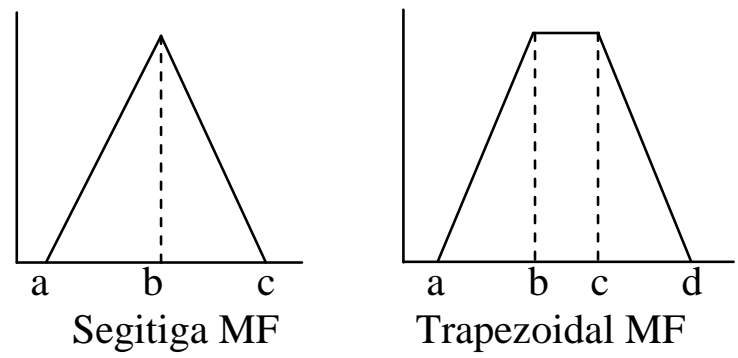

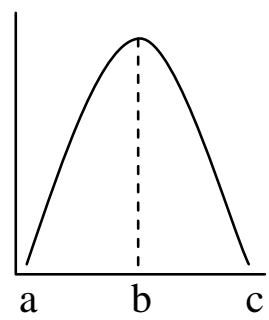

Gaussian MF

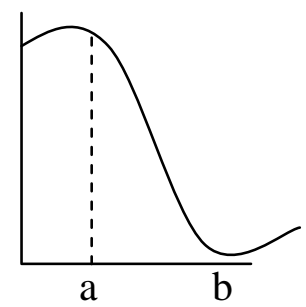

Sigmoid MF
Gambar 1. Jenis-jenis membership function
Perbandingan Antara Segitiga Samakaki

dengan Segitiga Siku-siku

Pada segitiga samakaki dapat dilihat pembentukan fungsi keanggotaan seperti terlihat pada gambar 2 .

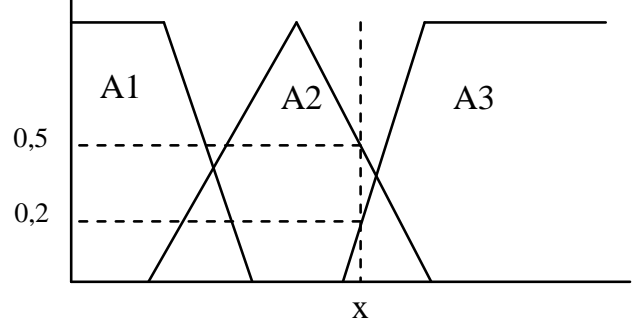

Gambar 2. Fungsi keanggotaan pada segitiga samakaki berikut:

Maka diperoleh fuzzifikasi sebagai

$\mu(\mathrm{x}=\mathrm{A} 2)=0,5$

$\mu(\mathrm{x}=\mathrm{A} 3)=0,2$

Jika dibanding dengan pembentukan fungsi keanggotaan pada segitiga siku-siku seperti terlihat pada gambar 3 .

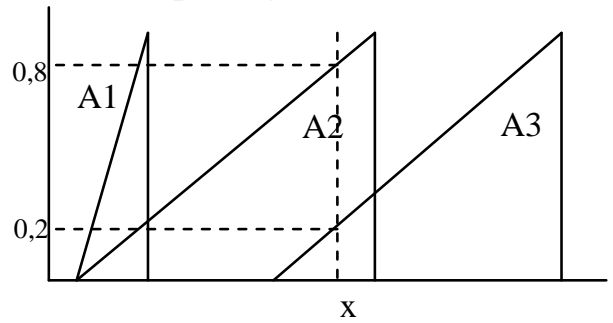

Gambar 3. Fungsi keanggotaan pada segitiga sikusiku

berikut

Maka diperoleh fuzzifikasi sebagai

$\mu(\mathrm{x}=\mathrm{A} 2)=0,8$

$\mu(\mathrm{x}=\mathrm{A} 3)=0,2$

\section{Hasil dan Pembahasan}

Dalam hasil dan pembahasan ini contoh kasus yang dibuat adalah penetapan status keaktifan mahasiswa, dengan dua variabel, yaitu: variabel pembayaran uang kuliah (x) dan variabel kehadiran perkuliahan (y). Sedangkan terdapat 3 variable linguistic yaitu: Tidak aktif (A1), Setengah Aktif (A2), Aktif (A3). Dimana terdapat 9 aturan (rule evaluation) yaitu: 
IF $\mathrm{x}$ is $\mathrm{A} 3 \mathrm{AND} \mathrm{y}$ is $\mathrm{B} 3$ THEN $\mathrm{z}$ is $\mathrm{C} 1$

IF $x$ is $A 3$ AND $y$ is $B 2$ THEN $z$ is $C 2$

IF $x$ is $A 3$ AND $y$ is $B 1$ THEN $z$ is $C 3$

IF $x$ is $A 2$ AND $y$ is $B 3$ THEN $z$ is $C 4$

IF $x$ is $A 2$ AND $y$ is $B 2$ THEN $z$ is $C 5$

IF $x$ is $A 2$ AND $y$ is $B 1$ THEN $z$ is $C 6$

IF $x$ is $A 1$ AND $y$ is B3 THEN $z$ is $C 7$

IF $\mathrm{x}$ is $\mathrm{A} 1 \mathrm{AND} \mathrm{y}$ is $\mathrm{B} 2$ THEN $\mathrm{z}$ is $\mathrm{C} 8$

IF $\mathrm{x}$ is $\mathrm{A} 1 \mathrm{AND} \mathrm{y}$ is $\mathrm{B} 1$ THEN $\mathrm{z}$ is $\mathrm{C} 9$

Membangun Fungsi Keanggotaan dengan Segitiga Samakaki

a. Fuzzifikasi

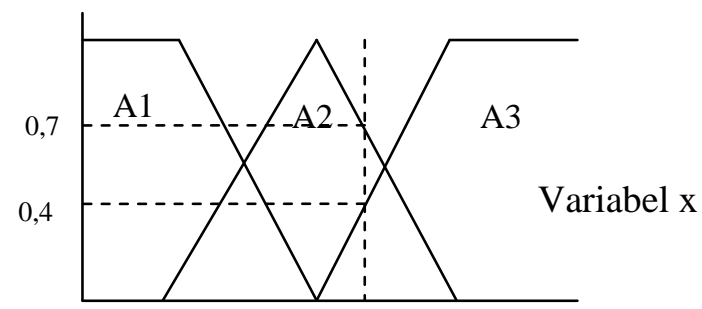

Gambar 4. Proses fuzzifikasi variabel $\mathrm{x}$ segitiga samakaki

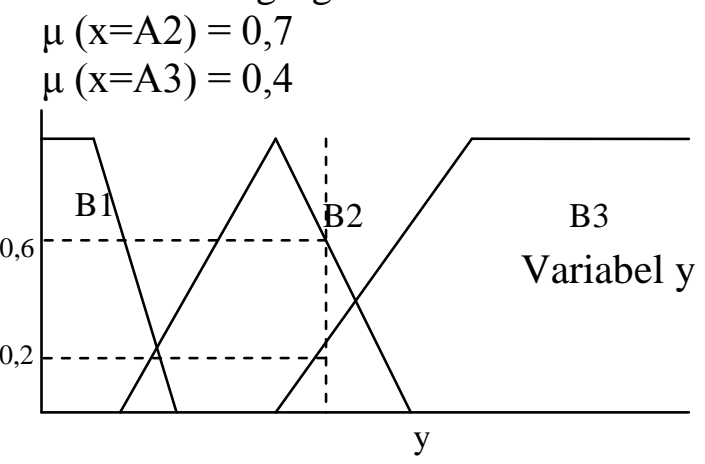

Gambar 5. Proses fuzzıtikasi variabel y segitiga samakaki

$$
\mu(\mathrm{y}=\mathrm{B} 2)=0,6
$$$$
\mu(\mathrm{y}=\mathrm{B} 3)=0,2
$$

\section{b. Rule Evaluation}

Rule Evaluation sebagai berikut:

IF $x$ is $\mathrm{A} 3(0,4)$ AND $y$ is $\mathrm{B} 3(0,2)$ THEN $\mathrm{z}$ is C1 $(0,2)$

IF $x$ is $\mathrm{A} 3(0,4)$ AND $y$ is $\mathrm{B} 2(0,6)$ THEN $\mathrm{z}$ is $\mathrm{C} 2(0,4)$

IF $x$ is $\mathrm{A} 3(0,4)$ AND $y$ is $\mathrm{B} 1(0,0)$ THEN $\mathrm{z}$ is C3 $(0,0)$
IF $\mathrm{x}$ is $\mathrm{A} 2(0,7) \mathrm{AND} y$ is $\mathrm{B} 3(0,2)$ THEN $\mathrm{z}$ is $\mathrm{C} 4(0,2)$

IF $x$ is $A 2(0,7)$ AND $y$ is $B 2(0,6)$ THEN $z$ is C5 $(0,6)$

IF $x$ is $\mathrm{A} 2(0,7)$ AND $y$ is $\mathrm{B} 1(0,0)$ THEN $\mathrm{z}$ is C6 $(0,0)$

IF $x$ is $\mathrm{A} 1(0,0)$ AND y is B3 $(0,2)$ THEN $\mathrm{z}$ is $\mathrm{C} 7(0,0)$

IF $x$ is $\mathrm{A} 1(0,0)$ AND $y$ is $\mathrm{B} 2(0,6)$ THEN $\mathrm{z}$ is C8 $(0,0)$

IF $x$ is $\mathrm{A} 1(0,0)$ AND $\mathrm{y}$ is $\mathrm{B} 1(0,0)$ THEN $\mathrm{z}$ is C9 $(0,0)$

c. Defuzzifikasi

Pada tahap defuzzifikasi ini metode yang dipakai adalah dengan metode centroid, seperti terlihat pada gambar 6 .

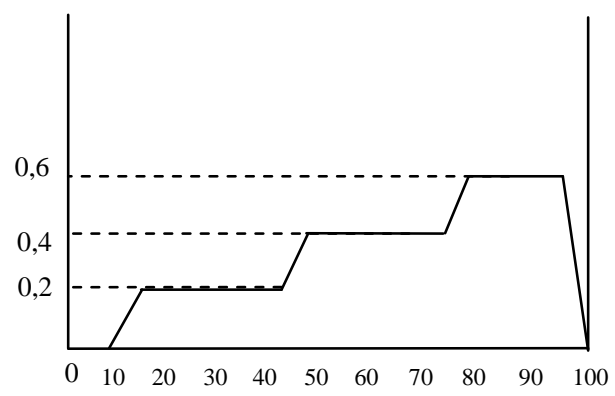

Gambar 6. Proses defuzzifikasi dari segitiga samakaki dengan metode centroid

$\mathrm{COG}=$

$(10+20+30+40) * 0,2+(50+60+70) * 0,4+(80+90) * 0,6$

$0,2+0,2+0,2+0,2+0,4+0,4+0,4+0,6+0,6$

$=\frac{194}{2,8}$

$=69,28$ 
Membangun Fungsi keanggotaan dengan Segitiga Siku-siku

a. Fuzzifikasi

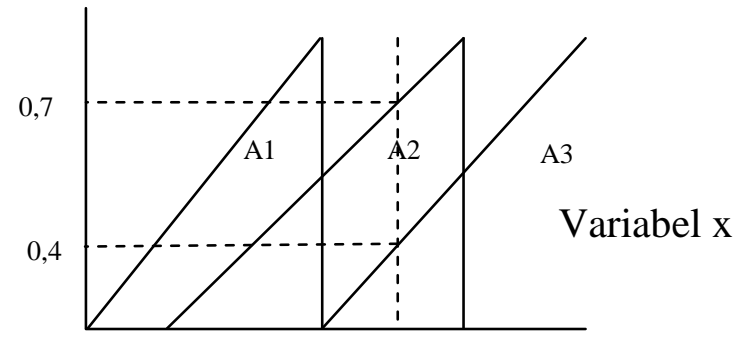

Gambar 7. Proses fuzzifikasi variabel $\mathrm{x}$ segitiga siku-siku

$\mu(\mathrm{x}=\mathrm{A} 2)=0,7$

$\mu(\mathrm{x}=\mathrm{A} 3)=0,4$

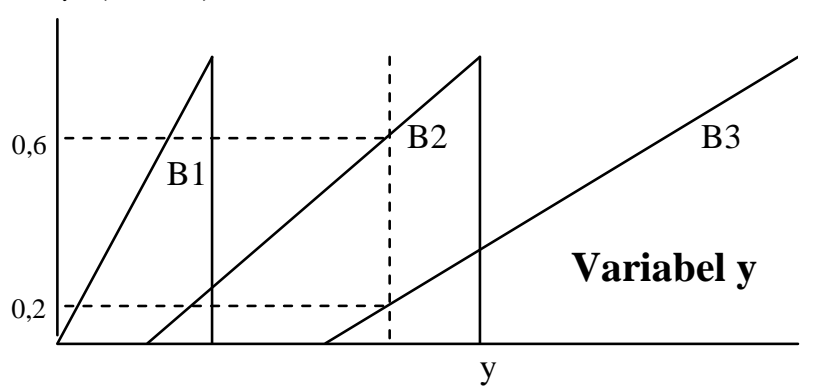

Gambar 8. Proses fuzzifikasi variabel y segitiga siku-siku

$\mu(\mathrm{y}=\mathrm{B} 2)=0,6$

$\mu(\mathrm{y}=\mathrm{B} 3)=0,2$

b. Rule Evaluation

Rule Evaluation sebagai berikut:

IF $\mathrm{x}$ is $\mathrm{A} 3(0,4)$ AND $\mathrm{y}$ is $\mathrm{B} 3(0,2)$ THEN $\mathrm{z}$ is $\mathrm{C} 1(0,2)$

IF $\mathrm{x}$ is $\mathrm{A} 3(0,4)$ AND $\mathrm{y}$ is $\mathrm{B} 2(0,6)$ THEN $\mathrm{z}$ is $\mathrm{C} 2(0,4)$

IF $x$ is A3 $(0,4)$ AND y is B1 $(0,0)$ THEN $z$ is $\mathrm{C} 3(0,0)$

IF $\mathrm{x}$ is $\mathrm{A} 2(0,7)$ AND $\mathrm{y}$ is $\mathrm{B} 3(0,2)$ THEN $\mathrm{z}$ is $\mathrm{C} 4(0,2)$

IF $\mathrm{x}$ is $\mathrm{A} 2(0,7)$ AND $\mathrm{y}$ is $\mathrm{B} 2(0,6)$ THEN $\mathrm{z}$ is $\mathrm{C} 5(0,6)$

IF $\mathrm{x}$ is $\mathrm{A} 2(0,7)$ AND $\mathrm{y}$ is $\mathrm{B} 1(0,0)$ THEN $\mathrm{z}$ is $\mathrm{C} 6(0,0)$

IF $\mathrm{x}$ is $\mathrm{A} 1(0,0)$ AND $\mathrm{y}$ is $\mathrm{B} 3(0,2)$ THEN $\mathrm{z}$ is $\mathrm{C} 7(0,0)$
IF $\mathrm{x}$ is $\mathrm{A} 1(0,0)$ AND $\mathrm{y}$ is $\mathrm{B} 2(0,6)$ THEN $\mathrm{z}$ is $\mathrm{C} 8(0,0)$

IF $\mathrm{x}$ is $\mathrm{A} 1(0,0)$ AND $\mathrm{y}$ is $\mathrm{B} 1(0,0)$ THEN $\mathrm{z}$ is $\mathrm{C} 9(0,0)$

\section{c. Defuzzifikasi}

Pada tahap defuzzifikasi ini metode yang dipakai adalah dengan metode centroid seperti terlihat pada gambar 9 .

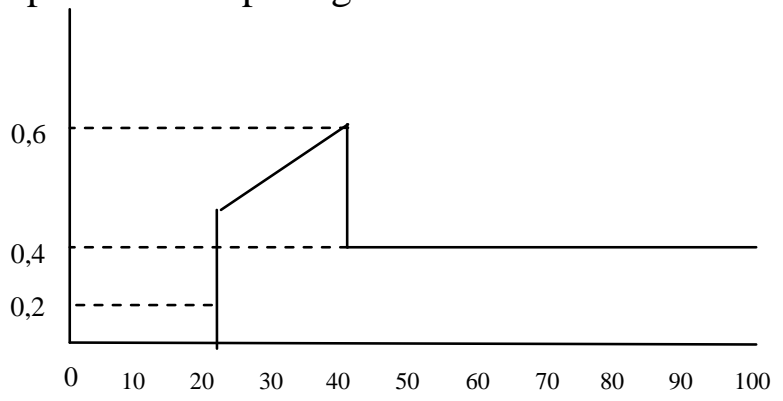

Gambar 9. Proses defuzzifikasi dari segitiga siku-siku dengan metode centroid

$\mathrm{COG}=$

$$
\begin{aligned}
& \frac{(30+40) * 0,6+(50+60+70+80+90+100) * 0,4}{0,6+0,6+0,4+0,4+0,4+0,4+0,4+0,4} \\
& \quad=\frac{222}{3,6} \\
& =61,66
\end{aligned}
$$

\section{Kesimpulan}

Perbandingan yang dilakukan terhadap segitiga samakaki dan segitiga siku-siku dalam menentukan fungsi keanggotaan fuzzy set adalah membangkitkan fungsi keanggotaan (MF) pada segitiga siku-siku bisa dihitung dan menghasilkan nilai yang mendekati nilai $\mathrm{MF}$ pada segitiga samakaki dengan menggunakan algoritma fuzzy Mamdani. Terdapat perbedaan antara hasil MF segitiga siku-siku dengan MF segitiga samakaki, dengan satuan nilai 7,62 dalam range 100. 
JURASIK (Jurnal Riset Sistem Informasi \& Teknik Informatika)

ISSN 2527-5771

Volume 1, Nomor 1, Juli 2016

\section{Daftar Pustaka}

Arslan. A, Kaya. M (2001), Determination of Fuzzy Logic Membership Functions Using Genetic Algorithms, 01650114/01 Elsevier Science, p 297-306.

Chen. J.E, Otto. K.N (1995), Constructing Membership Functions using Interpolation and Measurement Theory, 0165-0114/95 Elsevier Science, p 313-327.

Hong. TP, Lee. CY (1996), Induction of Fuzzy Rules and Membership Functions from training Examples, 0165-0114/96 Elsevier Science, p 33-47.

Kim. C.J, Russell. B.D (1993), Automatic Generation of Membership Function and Fuzzy Rule Using Inductive Reasoning, 0-7803-1485-9/93 IEEE, $\mathrm{p}$ 93-96.

Lucero. YC, Nava. PA, A Method for membership Function generation from training Samples, University of Texas.

Shi. Y, Sen. PC, Fellow, Effects of Different Slopes of embership Functions on the Fuzzy Control of DC-DC Converters, IEEE, p 1160-1165.

Sugeno.M, Yasukawa. T (1993), A FuzzyLogic-Based Approach to Qualitative Modeling, IEEE Transactions on Fuzzy Systems Vol. 1 No.1.

Tamaki. F, Kanagawa. A, Ohta. H (1998), Identification of Membership Functions Based On Fuzzy Observation Data, 0165-0114/98 Elsevier Science, p 311-318.

Turksen. B, Bilgic. T (1995), Measurement of Membership Functions: Theoretical and Empirical Work.

Zhao.J, Bose. BK (2002), Evaluation of Membership Functions for Fuzzy Logic Controlled Induction Motor Drive. 07803-7474-6/02 IEEE, p 229- 234 